\title{
FOREIGN LANGUAGE EDUCATION IN NIGERIA AND THE DEVELOPMENT OF ENTREPRENEURIAL SKILLS AMONG LEARNERS
}

\author{
ARAROMI M. OLAKUNLE \\ YINUSA AMINAT OLADUNNI \\ Dept. of Teacher Education, University of Ibadan, Nigeria
}

\begin{abstract}
Foreign language education has not been given a pride of place in Nigeria due to poor policy implementation and negative attitude towards the teaching and learning of the languages. The rate of unemployment experienced by graduates of foreign languages has reached an alarming level and this has generated a concern among stakeholders in the field of foreign languages in Nigeria. Graduates of foreign languages are not expected to be redundant, jobless or unemployed or rely entirely on teaching jobs to survive as some people in some quarters frequently claim. Stakeholders in foreign language education have failed to take critical look at the curriculum content of the various foreign languages on the curriculum to see whether they are relevant to the socio-economic realities and values in Nigeria. This paper however seeks to examine the curriculum content of the foreign languages on the curriculum with the view to ascertaining their relevance to the socio economic realities and values in Nigeria. It was affirmed that the content of the foreign language curriculum should be able to meet the vocational and entrepreneurial needs of the teeming unemployed youths in Nigeria. There is urgent need to disabuse the mind of people on the erroneous belief that the only career available for graduates of foreign languages is teaching career. We therefore recommended that government should focus more attention on the teaching of foreign languages for specific, technical and vocational purposes in order to resolve the problem of unemployment ravaging Nigeria as a country and African continent in its entirety.
\end{abstract}

Keywords: Re positioning, re-engineering, foreign language curriculum, vocational needs.

\section{Introduction}

Languages are not only prerequisites for international commerce, they are also business drivers. They drive economic growth, creates job and foster global competitiveness, (Fenstermacher \& Lawless, 2012). Human language is a phenomenon that differentiates humans from animals even though animals are said to have their language or code of communication which varies from one species of animal to the other. In this world of globalization and information and communication technology, the ability to communicate in diverse world languages is a great asset that is unquantifiable. The problem of mass unemployment of teeming population of the youth has engineered people's mind towards revitalization and overhauling of the existing curriculum at all levels of education to incorporate vocational and entrepreneurial studies. However, the knowledge of varieties of languages especially languages that are internationally recognized will further strengthens the chances of unemployed graduates either to be self-employed or get appointments with multinational firms.

\section{General overview of language and entrepreneurial skills}

Nigeria exhibits high level of entrepreneurship which led to the creation of business enterprises, both new and old industries. Entrepreneurship cannot be achieved without effective language and communication skills. Product, services, information emerging from entrepreneurship which generates interest and economic value is possible through the use of a language that has world-wide appeal. Rosendahl, Randolph and 
Sloof (2012) and Shehu and Shittu (2015) posit that entrepreneurship is a key factor to increase economic growth and innovation. Therefore, English language brings about economic security of most countries in Africa as they depend on it for their negotiation and marketing skills. Shehu and Shittu (2015) assert that the use of English has become a critical factor in the success of any enterprise.

Shehu and Shittu affirm that the economic security of African countries depend on negotiation and marketing skills, this means that their effectiveness or otherwise in the global market may be determined by the extent to which their entrepreneurs possess a good command of English. Entrepreneurial activity as well as better communication in English can boost economic prospects and open the doors to the world market.

Entrepreneurs in Africa strive to find a place in global commerce and trade, so adopt English as their preferred language of communication. Therefore, entrepreneurship education is essential not only to shape the mindset of young people but to provide the skills and knowledge that are central to developing an entrepreneurial culture, (Rosendahl, Rosendal \& Sloof, 2012).Ozdemir (2015) says studying a passage which contains some messages about entrepreneurship may be inspired to students in language class and using reading passages which gives the idea of entrepreneurship or innovation.

Ozdemir (2015) concludes that no matter what the level and the complexity of the activities are, the focus is on both teaching English and creating an entrepreneurial mindset. It is extremely important that students not only have the qualifications to survive in today's highly competitive world but also to think and behave like an entrepreneur, having the necessary qualifications and using them to create new ventures which makes the future of the nation get the welfare they deserve. However, entrepreneurship is seen as one of the life buoys to save the world's economy in the future, it is vital to provide students with skills to think and behave like entrepreneurs. EFL classes with a rich mixture of activities present golden opportunities to achieve the aim. It must not be hard to redesign some of the activities in an English class in such a way to create an entrepreneurial mindset and to contribute to the welfare of not only a person, a country, or maybe the whole world, (Ozdemir, 2015). Therefore, language is undoubtedly the blood of entrepreneurship, (Shehu \& Shittu, 2015).

Proficiency in English according to Roshid and Chowdhury (2013) is needed for employees to advance in both local and international companies and to compare their technical knowledge and skills. It provides a foundation for what has been called process skill, problem solving and critical thinking skills that are needed to cope with the rapidly changing environment of the global workplace where English plays an increasingly important role, (Roshid \& Chowdhury, 2013). Ekpe (2010) says the ability to speak English enhances one's opportunity in securing good employment in Nigeria. Interviews for employments are conducted in English language no matter the nature of the work. Roshid and Chowdhury, 2013 state that proficiency in English has deep influence on job market, especially in a country where English is the main language of the host country. Studies have established that across a wide range of settings, English language fluency is associated with higher salary. English language aptitude works as one of the important determining factors to get a job, to earn higher 
salary, and get other advantages in employment market. Therefore, English is a ticket for securing employment, (Ekpe, 2010).

\section{Status of English language in Nigeria}

English plays an important role in the formation of the national expectation and integration of the Nigerian nation through its 'official language' status. It enjoys its primacy in the formation of political and educational system as a medium of instruction in schools along with the three crucial indigenous languages Yoruba, Hausa and Igbo languages (Danladi, 2013). English has been the most unifying factors in Nigeria and has been the means of socio-economic uplift for many individuals (Diri, 2011).English in Nigeria is seen as a weapon because it provides an excellent representation of politics supremacy (Danladi, 2013). Olofin (2012) states that the status of English as a world language provides various avenue for global communication, science and technology, international business, diplomatic relations and human development, which could have been difficult to achieve if Nigeria has not adopted English as a second language.

\section{Importance of English language}

The world is an increasingly globalized place where individuals are communicating among multiple cultures. English in Nigeria is experienced in the domains of politics, education, legal matters, administration, mass media, art, leisure, publication and quest for national unity. This is why Danladi (2013) posits that English language gives an individual the sense of oneness, unity and loyalty. It is a weapon that provides an excellent representation of political supremacy.

In academic development, English plays a crucial role in empowering learners with the capabilities necessary for lifelong learning, critical thinking, problem-solving, creativity and innovation for adapting to the rapid changes and demands of society. English opens up a world of leisure and entertainment of learners, (Curriculum Development Council and the Hong Kong Examination and Assessment Authority, 2007). English is the only language given prominence by both teachers and pupils. Speaking English language by primary school pupils is encouraged by parents at home and teaching in schools. This is seen as a symbol of knowledge of western education and indication of class and status of the pupils and parents (Ekah, 2012).

Ezeokoli (2013) posits that English Language is one of the core subjects taught at the various levels of the Nigerian education system, especially the primary, secondary and even the pre-primary grades. In all levels of education in Nigeria, the English Language is the most widely used language of instructions in schools. This has been given backing by the Nigerian Educational Policy (2013) which makes it mandatory for the English to be the language of instructions in schools especially at the secondary and the tertiary levels.

English language is a compulsory subject from the pre-nursery to the university level (Ekpe, 2010; Fakeye, 2012; Ezeokoli, 2013; Kolawole, 2013). Obiegbu and Njemanze (2015) note that the essence of language teaching in school is to improve the communicative competence of students in English Language. Fakeye (2012) states that the knowledge of English language help students in understanding other school 
subjects since it is used to teach all other subjects except indigenous languages. English language serves as a filter of entry into any tertiary institution in Nigeria (Ekpe, 2010). Good command of English is a sign of good education and anyone who does not speak the language is regarded as uneducated. The essence of studying any language is to enable the language learners to be competent in the language and to be able to communicate in the language effectively (Vero-Ekpris, 2012). Yusuf (2012) conclude that English is the language of integration in Nigeria amidst the compounding complexity indigenous languages and the only language that indexes the spirit of togetherness.

\section{Economic Value of learning English Language}

Economists in Nigeria believe that English is crucial for economic growth, as it helps to trade on an international scale (Obiegbu, 2015). The international community can easily and comfortably be reached because of the prestigious language - English. English language skills enhance business and trade and improve an individual's economic conditions. An individual's economic empowerment in Nigeria is closely linked with good command of English. A wide range of business categories in Nigeria including the banking industry, technology, the pharmaceutical industry and even vocational workers such as carpenters and electricians see increased need for English language skills. Obiegbu (2015) posits that a professional with good English language skills can earn an average of thirty percent (30\%) more than someone with no English language skill in Nigeria. The government of Nigeria firmly recognized that English is a key element of business communication and it is essential for attracting new investments. Thus, English language is a tool for sustained national development.

\section{Career prospects in the learning of French Language}

The first trading company to be established in Nigeria is CFAO which was established in 1902.The trade relationship between France and Nigeria has started since the attainment of political independence in 1960 especially during the period of oil boom. It is on record that the French exports to Nigeria had reached 13.2 billion Naira in 1993. Nigeria government has signed numerous trade and corporation agreement with France over the years. One of the trade agreement signed by Nigeria and France was the agreement signed between Obafemi Awolowo University and University of Bordeaux France in 1979 which would promote the mutual exchange of personnel in the field of administration, history, sociology and political science.

Suffice to say that France, as one of the advanced countries of the world, contributes immensely to the economic development of Nigeria in view of the number of multinational firms such as Elf, Michelin, Total, Peugeot, Berliet Saviem Nigeria limited, the Société Générale Bank, la Compagnie Française de l'Afrique Occidentale (CFAO), just to mention a few (Mbuko,2000). Mbuko further reiterated that the Nigerian Government must pay special attention to commercial, technical and scientific French in order to facilitate the technological and economic development of the country through the medium of the French language. Araromi (1981) noted that the advocacy for the teaching of Science and Technology would be aided by the teaching of functional French to the regular and the professional learners at the elementary level. 
French is indispensable to Nigerians and Nigeria as a nation. One of the reasons is that Nigeria is surrounded by Francophone West African countries and to crown it all, Nigeria is a member of many notable international organizations such as ECOWAS, AU, OPEC, where the Francophone countries constitute the larger percentage of the member states, in which Nigeria plays dominant roles and French is used as a language of communication (Mbuko, 2000). French language is also important in Nigeria because of the cultural value embedded in it. It could bring the rich culture of France and Francophone countries to the doorsteps of Nigerians.

In furtherance of the adoption of French as the second official language in Nigeria, the Federal government of Nigeria signed an agreement with the French government on Friday $20^{\text {th }}$ July 2008. This agreement saw the French government doling out the sum of 319.6 million naira for the support of French teaching and learning in the Nigerian system of education. According to the then Minister of Education, similar sum valued at 248 million naira was provided by the French government in 2002 bringing the total sum to $567,760,000$ naira committed by the French government to the enhancement of the teaching and learning of French language in Nigeria (Saturday Tribune, $21^{\text {st }}$ of June, 2008, Page 9).

There is no gainsaying the fact that communication through the medium of language aid to a large extent human development. This is because humans cannot communicate without the instrumentality of language. Information which is also vital and important in sustaining human existence is acquired through the medium of language. Access to opportunities that will open door for sustainable development and full development of one's potential both individually and collectively could only be acquired if one is knowledgeable in as many languages as possible.

As regard the teaching and learning of French as a language of international repute, different aims and purposes are discernable in the teaching and learning of the language. French as a liberal art subject is not only learnt for academic purpose. There might be some specialized or specific purpose of imparting the basic skills or knowledge in the language into the intending learners. Learners are equipped with the skills of listening, speaking, reading and writing in order to be able to perform certain duties or obligations. There is urgent need to disabuse the mind of people that learning French language could not only offer the learners teaching career.

There are two specific purposes for learning French as a foreign language i.e. occupational purpose and academic purpose. French could be taught under the domain of French for occupational purposes (FOP) to some professionals who are engaged in specific jobs such as pilots, hotel personnel, immigration officers, business men or women, engineers and other artisans. In a situation where French is taught to learners for academic purpose, emphasis is placed on competencies or skills in language such as academic writing, listening, note taking, making oral presentation etc (Owoeye, 2010).

The nature of global labour market requires the learning of additional languages. multilingualism is a viable pre-requisite or credential to get a job at the international market. Suffice to say therefore that monolingualism is no longer in vogue. It is gradually fading out in the present day labour market. The chances of getting job both locally and internationally will be enhanced with the ability to speak more than one 
international language and more importantly it opens up new horizons both personally and professionally. Therefore, speaking an additional language is great asset.

Looking critically at the significant value of learning French language and the career prospect inherent in the language, it would be expedient to examine the status of the language at the international level. It is important at this juncture to state that over 200 million people speak French language world over in about five continents of the world. The language is taught in all continents and it is the most widely learned foreign language after English language. The "'Francophonie", which is the organization of all the French speaking countries of the world comprises sixty eight member states and government. The economic influence of France as one of the advanced nations of the world is found almost in all nations of the world. France is the world fifth biggest economy which attracts entrepreneurs, researchers and top foreign students. There are many multinational companies whose working language is French language established in areas of business such as retailing, automotive, luxury goods and aeronautics. Graduates of French both at NCE or degree levels stand the chance of working in all the above mentioned multinational companies sited in Nigeria and thereby build a career in various fields of human endeavour.

Learning French language opens up a new and rich cultural horizon. It is an established fact that culture and language are two entities that are inseparable. Language is a vehicle that drives the culture of a given community and it is a medium through which the culture is showcased and expressed. The language could also serve as an instrument for codifying this cultural content of a language. Knowledge of French language is a voyage into the world of fashion, gastronomy, the arts, architecture and arts. The knowledge of French language gives access to the literary works of French writers such as Victor Hugo, Marcel Proust and Poets such as Charles Baudelaire and Jacques Prévert in the original. The entertainment industry is one of the lucrative industries not only in Nigeria but the world over. The Nigerian Nollywood has produced eminent artists and entertainers whose gift has thrown them into limelight. A great number of artists or theatre practitioners in Nigeria film industry earn their living in the industry without necessary relying on government for white collar jobs which are not readily available. One would not be surprised to know that a great numbers of francophone African novels by writers of French expressions have been converted to home videos. Example of such novels are Xala and Le Mandat by Sembene Ousmane and l'enfant Noir by CamaraLaye, Une vie de Bouy by Ferdinand Oyono. Artists from francophone countries participated actively in these movies because of their ability to communicate effectively in French language. A Nigerian graduate of French can also build a career in the entertainment industry. $\mathrm{He}$ or she can showcase his or her artistic potentials in the field of theatre, performing art, music, poetry, comedy and play writing. An ability to communicate both in English and French will automatically project the person into world of entertainment at the international scene. Furthermore, knowledge of additional foreign language will earn the individual concerned an international fame, versatility and flexibility to explore his or her potentials fully.

\section{Re-engineering foreign language curriculum for entrepreneurial development}

The aims, goals and objectives of learning languages at various levels of Nigeria educational system in Nigeria has been a major concern among experts and 
stakeholders in language education. The expectation of stakeholders in education is that learners should be able to use language beyond the school system and acquire competence in the language academically, linguistically and communicatively. Obanya (2002) is of the opinion that there should be a match between what is prescribed in the curriculum and what is practiced. He further affirmed that English language has been a restricted code among students in both tertiary and secondary school level and there is decline in the communicative competence and linguistic competence of the students.

The case of French language in Nigeria is even more pathetic because the students who studied French language while in school can only regurgitate the few sentences they memorized while studying French language in school but they cannot claim that they understand the meaning of the memorized sentences and they cannot hold conversation in the language for a long time. The use of French language beyond the school system is still a mirage among secondary schools graduates in Nigeria.

The students' ability to understand and use language in varied situations in real communicative situation is more important than describing and mastering the grammatical structures of the language. The emphasis placed on passing examination which has reduced curriculum to examination- oriented curriculum has denied the students opportunity to acquire communicative competence in the language. The need analysis of the students' communicative requirements should be of prime importance while designing language curriculum. The student-centered curriculum should be adopted as a viable approach to the teaching of language. The academic and communicative purposes of leaning language are both important and fundamental but emphasis being placed on academic purpose of learning language to the detriment of communicative purpose is not healthy for the inculcation of communicative competence in the learners. This is the reason why students who obtained credit pass in language in public examinations cannot express themselves in the language. There is advocacy for the use of authentic materials such newspapers and magazines as enrichment materials while teaching languages in schools. Over-reliance on textbooks for presenting language content to the students should be grossly discouraged. Classroom activities should be based on meaningful interaction in the language.

There is need for the stakeholders in education to reach consensus of opinion on the content of curriculum of foreign languages on the school curriculum. The curriculum planners should diversify the curriculum content to meet the entrepreneurial and vocational needs of the students. The language curriculum content appears to be too academic in nature. As a result of this, graduates of foreign languages always search for teaching appointments in schools after their graduation which attracts meager salary or remunerations. Graduate teachers of foreign languages always have the erroneous belief that teaching appointment is the only career opportunity available for them after graduation. Language curriculum should incorporate technical and vocational study or language for specific purposes. Curriculum planners should begin to look critically into training students of language for technical and vocational careers such as engineering, hotel management and carpentry etc. so that they can build career outside the teaching profession. 


\section{Conclusion}

The significant value of learning foreign languages such as English and French language to career development cannot be over- emphasized. One cannot undermine the prospect of language skills in the realization of human potential most especially languages that have international recognition and status. Government at all levels should invest massively in the teaching and learning of foreign languages so that the high rate of unemployment ravaging the entire population of the youths can be out rightly be reduced to the barest minimum through the instrumentality of language skills. It should be noted that knowledge of language opens a wide a range of opportunities to explore a wealth of experience documented in the languages that are uncommon to people. 


\section{References}

Araromi, M. O. (1981). L' enseignement du français dans les colleges techniques et polytechniques. L'expérienced' Ibadan'. A paper presented at the workshop on functional French held at the College of Technology, Owerri.

Curriculum Development Council and the Hong Kong Examinations and Assessment Authority, (2007). English language curriculum and assessment guide (Secondary 4 - 6) HKSARG.

Danladi, S. S. (2013). Language policy: Nigeria and the role of English language in the $21^{\text {st }}$ century. European Scientific Journal, 9: 1-21.

Diri, I. T. (2011). The English language as an instrument of exploitation in colonial Nigeria: instances from Icheoku. Journal of Languages and Culture, 2 (9): 148-153. http://www.academicjournals.org/JLC

Ekah, E. M. (2012). Regenerating English language teaching in Nigeria for selfreliance and national development. Journal of Resourcefulness and Distinction, 4 (1).

Ekpe, M. B. (2010). The English language in Nigeria, (ENG 353). National Open University of Nigeria (NOUN), Lagos. p. 1-215. Retrieved April 13th, 2013 from www.nou.edu.ng/

Ezeokoli, F. O. (2013). Effective and creative teaching of the English language. In Araromi, M. A. Moronkola, O. A., Ademokoya, J. A. (Eds.) Teaching and evaluation in regular and special secondary schools (An effective and creative approach). Royal People (Nigeria) Ltd. 222 - 226.

Fakeye, D. O. (2012). Predicting Students' achievement in English language from teachers' classroom behavior and teaching experience. European Journal of Educational Studies, 4 (2). Ozean Publication. Retrieved April 15, 2015 from http://ozelacademy.com/ejes4-2\%204\%29.pdf

Federal Republic of Nigeria, National Policy on Education, $6^{\text {th }}$ Edition (2013). NERDC Lagos, Nigeria.

Fenstermacher, H. and Lawless, A. (2012). Language drives economic growth, creates jobs, and fosters competitiveness for U.S. Businesses. A National Security Crisis: Foreign Language Capabilities in the Federal Government Monday, May 21, 2012 WRITTEN TESTIMONY.

Kolawole, C. O. O. (2013). Effective teaching of language at the secondary school level: teaching of English language as an example. In Araromi, M. A., Moronkola O. A., Ademokoya J. A. (Eds.) Teaching and evaluation in regular and special secondary schools (An Effective and Creative Approach) Royal People (Nigeria) Ltd. 215 - 219. 
Mbuko, L. (2000). French Essays on culture and civilization for schools and colleges. Bounty press Limited, Ibadan.

Obanya, P. (2002). 'Curriculum overload in the Language Education Programme for Basic Education' In Adebayo, L, Isiugo Abanihe, I., and Ohia, I.N. (Eds). Perspective on Applied Linguistics in Language and Literature, Ibadan: Stirling - Horden Publisher (Nig) Ltd.

Obiegbu, I. (2015). The English language and sustainable development in Nigeria. Open Journal of Political Science, 5: 82-86. http://dx.doi.org/10.4236/ojps.2015.52009.

Obiegbu, I. and Njemanze, Q. U. (2015). An assessment of the communicative and developmental needs of English language in a multilingual Nigeria. International Journal of English Language and Literature Studies, 4 (4). 161170.

Olofin, A. O. (2012). Effects of English language on nationaldevelopment.Greener Journal of Social Sciences, 2 (4): 134-139. www.gjournals.org

Ozdemir, P. 2015. A combined approach to teaching English and entrepreneurship. GlobELT: An International Conference on Teaching and Learning English as an Additional Language, Antalya - Turkey. Procedia - Social and Behavioral Sciences, 199: 293 - 297. http://creativecommons.org/licenses/by-nc-nd/4.0/

Rosendahl, L.; Randolph, H. \& Sloof, M. V. (2012). The effect of early entrepreneurship education: Evidence from a randomized field experiment, Tinbergen Instıtute Discussion Papers, http://www.tinbergen.nl

Roshid, M. M. and Chowdhury, R. (2013). English language proficiency and employment: A case study of Bangladeshi graduates in Australian employment market. Mevlana International Journal of Education (MIJE), 3 (1): 68-81. http://mije.mevlana.edu.tr/

Shehu, H and Shittu, K. O. (2015). The bridge to economic prosperity: the role of English language communication in Entrepreneurship. International Journal of Humanities and Social Science, 5 (7): July 2015189 -195 Center for Promoting Ideas, USA www.ijhssnet.com

Vero-Ekpris, G. U. (2012). Re-Engineering English language curriculum foe employment and self-productivity in Nigeria. Multidisciplinary Journals of Academic Excellence, 8 (1). 1-8 http://www.globalacademicgroup.com/

Yusuf, H. O. (2012). Language as a tool for national integration: the case of English language in Nigeria. International Journal for Cross-Disciplinary Subjects in Education (IJCDSE), Special Issue 2 (Issue 1): 1-8 http://infonomicssociety.org/IJCDSE 